\title{
„Úristen! Úton vannak a lengyelek": Egy morális pánik narratívája
}

\author{
SARÁNY ORSOLYA ${ }^{1}$
}

Az Európai Unió és a csatlakozó országok 2003. április 16-án írták alá az athéni szerződést, amely 10 ország európai uniós csatlakozásának alapjait fektette le. A bővítés várható negatív hatásai között az új tagországokból érkező vendégmunkások szabad munkaerő-áramlása előkelő helyet foglalt el. Ilyen vita folyt Hollandia parlamentjében is, amely végül úgy döntött, hogy 2006-ig lezárja határait az új munkaerő előtt, és a megnyitást követően is csak azokat a munkavállalókat fogadja be, akik azokban a gazdasági szektorokban vállalnának munkát, amelyben hiánnyal küzd a holland gazdaság. ${ }^{2}$

A vizsgált munka a holland kormány döntésének narratíváját vizsgálja, abban az öt hónapban, amely alatt megszületett a döntés a kelet-európai munkaerő bevándorlásának szabályozásáról. A dolgozat célja megvizsgálni, hogy a tömeges bevándorlástól való félelem megértésére mennyire alkalmas a morális pánik elmélete. A mű két kérdése:

Mennyire egyezett meg a parlamenti és a médiában lefolyt nyilvános vita a fenyegetettség mértékéről, illetve vannak-e a kormány döntését megelőző időszakban megjelenő eseményeknek morális aspektusai, azaz megfelel-e a morális pánik koncepciójának.

\footnotetext{
${ }^{1}$ Debreceni Egyetem, Szociológia és Társadalompolitika Doktori Program, e-mail: saranyorsi@gmail.com

${ }^{2}$ A többi EU-tagország sem szabott sokkal kedvezőbb feltételeket az új tagországokból érkező vendégmunkásoknak. Az akkori 15 tagállam közül csupán az Egyesült Királyság, Észak-Írország, illetve Svédország nyitotta meg határait, kisebb-nagyobb megszorításokkal az új keleti tagállamok munkavállalói számára (Drinkwater et. al. 2009), sőt: a többi ország által bevezetett intézkedések idővel még szigorúbbak lettek (Boeri - Brücker 2005). A legtöbb EU-s tagállam két évre lezárta a határait a külső munkaerő előtt, a munkavállalást pedig különböző engedélyekhez (munkavállalói, lakhatási) kvótákhoz kötötték, a keletiek munkavállalása pedig csak meghatározott időre szólt. Ám a tagországok nemcsak a munkavállalást, de a szociális juttatásokhoz való hozzáférést is szabályozták: Svédország kivételével - ott a keleti munkavállalók egyenlő bánásmódban részesültek - az összes tagállam korlátozta az új tagországokból érkezők szociális juttatásokhoz való hozzáférését (Boeri - Brücker 2005).
} 


\section{OLVASS FELESLEGESET!}

\section{Mi a morális pánik?}

A morális pánik koncepcióját Stanley Cohen brit szociológus dolgozta ki az 1970-es években (Cohen 1980). A témával számos magyaroszági szakember is foglalkozott (lásd Kitzinger 2000, Erős 2015), s Cohen művének egy részét a Replika is közölte (Cohen 2000). A morális pánik jelenségét sokan kutatták (Thompson 1998, Snel $2003^{3}$ ), és noha a különböző feldolgozások számos eltérést mutatnak be, van három közös elemük:

1. morális pánik akkor alakul ki, hogyha a társadalom azt észleli, hogy valami fenyegeti a morális értékrendet;

2. vannak „morális vállalkozók”, akik felhívják a figyelmet az értékrend „veszélyeztetettségére";

3. vannak bünbakok (folk devils), akik fenyegetik az értékrendet.

Cohen szerint a morális pánik folyamata a következő: „Egy csoport vagy egy bizonyos csoporthoz kapcsolódó jelenség az adott társadalom idealizált rendjét (hagyományos életmódját vagy alapvető értékrendszerét, konstruált, konszenzuális valóságát) fenyegető veszélyként tudatosul a társadalom tagjaiban. A média szenzációkeltő és leegyszerűsítő bemutatása nyomán a fenyegetést hordozó csoport könynyen azonosíthatóvá válik. A médiának ez a tevékenysége autoritatív megoldásokat sürgető közhangulatot alakít ki. A hatóságok erre az igényre törvényi szigorításokkal válaszolnak. A fokozott intézményi és közfigyelemhatásra növekszik a jelenség regisztrált eseteinek száma, így legitimálva a rend helyreállítását" (Kitzinger 2000: 23-24).

Goode and Ben-Yehuda (1994) elmélyítette Cohen elméletét, és öt kritériumot adott hozzá: 1) társadalmi nyugtalanság a fenyegetettség miatt, 2) ellenségesség a fenyegetőkkel szemben, 3) társadalmi egyetértés abban, hogy a problémát meg kell oldalni, 4) elpárolgás, azaz a pánik intenzitása idővel csökken, illetve 5) túlzott médiabeli figyelem.

\section{Mit teszünk, ha pánikolunk?}

Hogyha a társadalom úgy érzékeli, hogy a morális értékrend veszélyben van, azonnal megerősíti, és jól láthatóvá teszi az értékrendjének határait. A fenyegetett társadalom szerint a kívülállók (vagyis ők) összeférhetetlenek a saját (vagyis a Mi) értékrendünkkel. Ilyenkor az Ők sztereotipizálása, a Mi és az Ők elkülönítése törté-

\footnotetext{
${ }^{3}$ A morális pánikról az utóbbi időben Magyarországon a 2015-ös menekültválság, a magyar idegenellenesség kontextusában írtak többet, lásd: Messing - Ságvári 2016, Bernat - Sik - Simonovits 2015, Bernáth - Messing 2015, Simonovits - Bernát 2016, Lázár - Sik 2019, Gerő - Sik 2020.
} 


\section{OLVASS FELESLEGESET!}

nik meg, a társadalom elfogadott értékei, normái előtérbe kerülnek, s a megerősített értékrendhatárokat Ők nem léphetik át.

A különböző elméletek kialakítói a média morális pánikban betöltött szerepében sem értenek egyet. Míg Cohen (1980), valamint Goode és Ben-Yehuda (1994) nem tulajdonít nagy szerepet a médiának, Thompson (1998) szerint annak van a legnagyobb szerepe a pánikkeltésben. Critcher (2003) Thompsonnal ért egyet abban, hogy a morális pánikok eltorzulása sokszor a túlzott médiatizáltság eredménye.

Pijpers a Critcher (2003) által javasolt módszertant alkalmazza az elemzés során. Ez a morális pánik nyolc egymásra épülő mozzanatát különíti el.

A Critcher-féle nyolclépcsős modell:

\begin{tabular}{|l|l|l|}
\hline 1 & A „kezdet” & Újdonság, fenyegetés \\
\hline 2 & Média & $\begin{array}{l}\text { Sztereotipizálás, túlzás, torzítás, előrejelzés és szimbólum- } \\
\text { gyártás - a búnbak(ok) megneveztetnek }\end{array}$ \\
\hline 3 & $\begin{array}{l}\text { Mit és hogyan kell } \\
\text { tenni? }\end{array}$ & $\begin{array}{l}\text { Morális vállalkozók megjelenése - ők az erkölcs csőszei, } \\
\text { akiknek „munkaköri leírásába” tartozik a pánik tolmácsolá- } \\
\text { sa, amit a média „megmagyaráz” }\end{array}$ \\
\hline 4 & Szakértők bevonása & $\begin{array}{l}\text { Válaszok a 3. fázis kérdéseire, amit a média hitelesít - a } \\
\text { szakértők bevonása az elit bevonódását jelenti }\end{array}$ \\
\hline 6 & $\begin{array}{l}\text { Az elit szerepe: } \\
\text { egyetértésre való } \\
\text { törekvés }\end{array}$ & $\begin{array}{l}\text { Az elit jelzi a fenyegetést, a döntéshozók jelentős része pedig } \\
\text { egyetért abban, hogy ez ellen védekezni kell. A társadalom } \\
\text { nagy része ellenséges a búnbakokkal szemben. }\end{array}$ \\
\hline 7 & Megoldás, lebonyo- & $\begin{array}{l}\text { Megoldások javaslása és elfogadása - ezek lehetnek törvé- } \\
\text { nyek, szabályok. A megoldásnak szimbolikus jelentősége } \\
\text { van: megerősíti a társadalomban, hogy az elit foglalkozik a } \\
\text { kérdéssel. }\end{array}$ \\
\hline 8 & Örökség & $\begin{array}{l}\text { A megoldás a pánik „elpárolgását” hozza magával, a figyelem } \\
\text { más irányba terelődik. }\end{array}$ \\
\hline
\end{tabular}

Forrás: Critcher 2003: 151-153.

A szerző a pánik leírásához a narratológia módszerét használja. A narratológia lényege egy esemény részletes, kronologikus leírása. A bemutatott esetben például a szerző a narratológia felépítéséhez sajtóanyagokat és parlamenti szövegeket használ, azzal a céllal, hogy a holland parlamentben és közbeszédben lezajlott vitát bemutassa. A tanulmány szerzője az elemzésben nyomtatott lapok anyagait - híreket, háttérelemzéseket, valamint véleményeket -, audiovizuális anyagokat - tévé- és rádióhíreket, interjúkat, dokumentumfilmeket -, illetve más nyomtatott vagy elektromos forrásokat használ fel a történet rekonstruálásához. A begyűjtött anyagok öt 


\section{OLVASS FELESLEGESET!}

hónapot fednek le, a 2003 szeptembere és 2004 februárja közötti időszakot, amelyen belül az események csúcspontját a bevándorlói kvóta 2004. január 23-i elfogadása jelenti.

A narratológia, véleményem szerint, nem tekinthető tudományos kutatási módszertannak, legfeljebb eszköznek, amely segítheti a kutatót abban, hogy előkészítsen szövegeket, eseményeket mélyebb vizsgálathoz, esetleg ok-okozati összefüggéseket feltárjon, indokoljon. Tehát egy probléma részletes leírásához, egy kutatás felvezetéséhez tökéletes megoldás, ám módszertannak gyenge.

A szerző tudatában van a narratológia hátulütőinek is, annak kritikáit is ismerteti, s tisztában van a Critcher-féle nyolclépcsős módszertan hiányosságaival is, hogy például nem minden esetben lehet az összes szereplőt (bűnbakok, szószólók, morális vállalkozók stb.) beazonosítani, hogy a morális vállalkozók és a szakértők között nem mindig lehet különbséget tenni.

\section{A holland helyzetre alkalmazott morális pánik modell}

Hollandiában a kétezres évek elején a bevándorlás nem volt új jelenség. Erik Snel (2003) három morális vállalkozót azonosított, akik e témának „gazdái” voltak:

1. Pim Fortuyn: jobboldali politikus, aki a nem asszimilálódó bevándorlókból gyártott bűnbakot, és a bevándorlást kívánta szabályozni és visszaszorítani.

2. Ayaan Hirsi-Ali: a Holland Liberális Konzervatív Párt tagja, maga is egy sikeresen integrálódott muszlim fekete nő, aki az integrációt népszerűsítette.

3. Paul Scheffer: publicista, bevándorlásellenes esszéista, aki az akkori bevándorlást a holland kultúra elleni merényletnek kiáltotta ki.

E három szereplő a morális értékek fenyegetettségének hangsúlyozásával vagy ennek tagadásával teremtették meg a morális pánik alapját a holland társadalomban.

A következőkben a szerző által alkalmazott narratívát fogom bemutatni, de azt, a szerző javaslatai alapján, hat lépcsőre egyszerűsítve. A módszertan esetlenségét igazolja, hogy a javasolt nyolc lépcső nem abban a sorrendben jelenik meg a holland narratívában, ahogy azt Critcher javasolja, az eredeti tipológiában szereplő lépcsők gyakran átfednek, összeolvadnak (az eredeti critcheri lépcsőkre zárójelben utalok).

1. Egy parlamenti megszólalás (a critcheri modellben - 1. $A$ „kezdet”): A morális pánik első lépése az volt, amikor egy parlamenti képviselő arra hívta fel a figyelmet, hogy a holland parlamentben soha nem volt vita a bevándorlásról, márpedig a gazdasági lassulás miatt a holland munkaerőpiacon emelkedni fog a munkanélküliség, aminek nem fog jót tenni az olcsó kelet-európai munkaerő bevándorlása (2003 ősze). A parlamenti képviselő emlékeztette a parlamentet arra, hogy az athéni szer- 


\section{OLVASS FELESLEGESET!}

ződés megengedi, hogy az EU-tagállamok, akár hét évre, lezárják határaikat a bevándorlók előtt. A felszólalás hatására a Szociális és Foglalkoztatási Ügyek Minisztériuma egy tanulmányt rendelt a bevándorlás pozitívumairól és negatívumairól. (2004. szeptember 24.)

2. Igénymegfogalmazások (a critcheri modellben - 3. Mit és hogyan kell tenni?, 5. Az elit szerepe: egyetértésre való törekvés): A Szociális és Foglalkoztatási Ügyek miniszterét egy tévéműsorban kérdezik a bevándorlásról, kiemelve, hogy csak Lengyelországból 30 ezer bevándorló érkezhet. A miniszter szerint ezektől a számoktól nem kell tartani (október 28.), de több parlamenti képviselő elkezd a témával foglalkozni. Két kereszténydemokrata képviselő a bevándorlás hatásait akarja megismerni (november 6.), míg a kezdeményező konzervatív képviselő egyre nagyobb nyomást gyakorol a miniszterre (november 6.). Az alsóház az athéni szerződés ratifikásáról tárgyal, s noha az számos témát ölel fel, a legnagyobb vita a bevándorlás körül zajlik. Több párt a határok lezárását követeli, ahogy több nyugat-európai ország is teszi. Más pártok azonban ez ellen vannak. A parlament arról dönt, hogy döntés akkor születhet, amikor a tényleges számokat a bevándorlás pozitívumait és negatívumait taglaló tanulmányból megkapják a képviselők (november 19.).

3. Belép a média (a critcheri modellben - 2. Média): Felerősödik a média szerepe, ahol több történetben is megjelenik az olcsó lengyel munkaerő toposza, amely ellen a pro-Európa mozgalmakat hozzák fel. A parlamenti viták mellett a média mint a nép hangja szól, hátteret és véleményanyagokat fogyasztható módon szolgáltatva a diskurzushoz (2003 ősz-2003. december).

4. A diskurzus kiszélesedik (a critcheri modellben - 2. Média, 4. Szakértők bevonása): Ennek során sokféleképpen kapcsolódó témák jelennek meg. Egy olvasó például az illegális migráció meggátolását, és nem a határok lezárását kéri egy újságban. A Limburgs Dagblad több riportot közöl németországi és hollandiai lengyel munkásokról, amelyek hatására - noha a cikkek nem túldramatizáltak - a holland társadalom egy része tartani kezd a bevándorlástól (2003 ősz-2003. december). Egy közfinanszírozással foglalkozó professzor a bevándorlás ellen kampányol, kiemelve, hogy az a munkaerőpiaci versenyre és a szociális támogatásokra negatív hatással lehet (december 10.). Egy szakszervezet ezzel szemben a határok megnyitása mellett érvel, és egységes munkaerővándorlási szabályozás lefektetését javasolja EU-s szinten (december 19).

5. Kézzelfogható bizonyítékok gyártása (a critcheri modellben - 6. Megoldás, lebonyolítás): Megszületik a minisztérium által kért elemzés (január 14.) a bevándorlás várható hatásairól, amelyet a Holland Gazdaságpolitikai Elemzőiroda (CPB) készített el. A tanulmány szerint a bevándorlók az alacsony szintű, betöltetlen állásokat fogják elfoglalni, ezért kijelenthető, hogy a bevándorlás nem jelent veszélyt a holland értékekre és szociális hálózatra. A Szociális és Foglalkoztatottsági Ügyek Minisztériuma végül a határok részleges lezárása mellett dönt: 22 ezer bevándorlót 


\section{OLVASS FELESLEGESET!}

engednek be az országba, ha ennél több érkezik, a munkaerőpiacot lezárják (január 23.). Ez a döntés kompromisszum, amely ugyanakkor nem zárja ki további szigorítások bevezetését, nyilatkozta a miniszterelnök (január 23.). Ám több párt szerint a szabályozás nem elég szigorú, ezért a miniszter a további viták lefolytatása mellett dönt (február 4.).

6. Tetőpont (a critcheri modellben - 6. Megoldás, lebonyolítás, 7. A „vég”): A különböző vélemények hatására a miniszter a szigorításokat is bevezeti: a 22 ezer munkás csak megszabott munkára jelentkezhet, olyan munkákra, amelyeket a holland munkások nem vállalnának, s ezeknek nagyrészét is csak 2006 után foglalhatják el (február 13.). A döntés értelmében, ha a bevándorlás mértéke nagyobb, mint a jósolt, avagy az EU tovább bővül, és megjelennek a román és bolgár munkások, a mozgás szabadsága tovább korlátozható. Az idegen- és integrációs ügyek minisztere (Dutch Minister of Alien Affairs and Integration) 26 ezer elutasított menedékkérő kiutasítását javasolja. A hatalmas tüntetéseket és médiavisszhangot kiváltó javaslat elnyomja a lengyelek és a tömeges bevándorlás körüli vitát (február 3.).

\section{Összefoglalás, észrevételek}

A szerző szerint Critcher elmélete és módszertana megállja a helyét, ugyanakkor látható, hogy a szerző tagolása nem egyezik meg az eredeti elméletben szereplő nyolc lépcsővel, továbbá a szerző fel is cseréli a lépcsőket. Mi több, a holland helyzetben az egyes lépcsők fontossága sem azonos a morális pánik kialakulásában: a politikai nyomás erősebb volt, mint a média hatása. Ez megerősíti Critcher feltevését, miszerint nem a nép, hanem az elit észleli a fenyegetést, ők tudatosítják, erősítik fel és oldják meg a pánikot.

Az elemzett példa rávilágít egy fontos jelenségre, arra, hogy a migrációval kapcsolatos politikai döntéseket, a jelenség érzékeny volta miatt, a politikusok gyakran a félelem hatásaitól tartva hozzák meg. Láttuk, hogy hiába készítettek felmérést a bevándorlásról, nem az abból nyert adatoknak megfelelően cselekedtek, inkább lezárták a határokat s szabályozták a bevándorlók munkavállalását, noha a tanulmány azt állította, hogy a bevándorlók csak azokat a munkákat fogják elvégezni, amelyekre a hollandok nem jelentkeznek.

Szerintem a globalizált világban morális pánikot válthat ki a környezetszennyezés, környezeti csapások (mint éppen a közelmúltban láttuk, egy járvány), a világgazdaság lassulása, a technológiai fejlődés (például a kibertámadások), mivel ezek - egyéb hatásaik mellett - mind fenyegetik az emberek értékrendjét, életvitelét. Morális pánikot válthat ki továbbá egy álhír és/vagy a médiafogyasztás torzulása is: Székelyföldön például rettegnek attól, hogy az afrikai/ázsiai bevándorlók elveszik a munkát, holott Romániába nem is jönnek bevándorlók. Ez a félelem annak köszönhető, hogy a székelyföldiek magyarországi és nem erdélyi magyar médiát fo- 


\section{OLVASS FELESLEGESET!}

gyasztanak. Végül, a közösségi médiának köszönhetően, ma már a „nép” (vagy olyan szereplők, akik a Nép Hangjának tüntetik fel magukat) is lehet morális vállalkozó, hiszen minden eszköz megvan arra, hogy bárki azonosítsa, tudatosítsa, tolmácsolja, s ezáltal létrehozza vagy/és befolyásolja a morális pánik kialakulását és lefolyását.

\section{Irodalom}

Bernát, A. - Sik, E. - Simonovits, B. - Szeitl, B. (2015): Attitudes towards refugees, asylum seekers and migrants. TÁRKI, Budapest. http://www.tarki.hu/hu/news/ 2015/kitekint/20151203_refugee.pdf (Utolsó letöltés: 2020. 03. 18.)

Bernáth, G. - Messing, V. (2015): Bedarálva. A menekültekkel kapcsolatos kormányzati kampány és a tôle független megszólalás terepei. Médiakutató 16(4): 7-17. https://mediakutato.hu/cikk/2015_04_tel/01_menekultek_moralis_panik.pdf (Utolsó letöltés: 2020. 03.18.)

Boeri, T. - Brücker, H.: Why are Europeans Getting so Tough on Migrants? https://pdfs.semanticscholar.org/1a22/aae46846d56f24d73be3621db58585fd9bd6.pdf (Utolsó letöltés: 2020. 03. 18.)

Cohen, S. (1980): Folk Devils and Moral Panics: The Creation of the Mods and Rockers, St. Martin's Press, New York. Elérhető: https://infodocks.files.wordpress.com/ 2015/01/stanley_cohen_folk_devils_and_moral_panics.pdf (Utolsó letöltés: 2020. 03. 18.)

Cohen, S. (2000): Ifjú szörnyetegek. A modok és a rockerek megteremtése. Replika 40(6): 49-65. Elérhető: http://replika.hu/system/files/archivum/replika_4003_cohen.pdf (Utolsó letöltés: 2020. 03. 18.)

Critcher, C. (2003): Moral Panics and the Media. Open University Press, Buckingham.

Drinkwater, S. - Eade, J. - Garapich, M. (2009): Poles Apart? EU Enlargement and the Labour Market Outcomes of Immigrants in the United Kingdom. International Migration, 47(1). https://onlinelibrary.wiley.com/doi/full/10.1111/j.14682435.2008.00500.x (Utolsó letöltés: 2020. 03. 18.)

Erös, F. (2015): A morális pánikot a kormány szította, és a politika táplálja. Magyar Narancs. http://magyarnarancs.hu/belpol/eros-ferenc-a-moralis-panikot-akormany-szitotta-es-a-politika-taplalja-97092 (Utolsó letöltés: 2020. 03. 18.)

Gerő M. - Sik E. (2020): The Moral Panic Button In: Godziak, E. M. - Main, I. - Suter, B. (eds.): Europe and the Refugee Response, London, 39-58. https://www.taylorfrancis.com/books/e/9780429279317/chapters/10.4324/ 9780429279317-4 (Utolsó letöltés: 2020.03. 26.)

Goode, E. - N. Ben-Yehuda (1994): Moral Panics: The Social Construction of Deviance, Blackwell Publishers, Cambridge, US. https://dl.uswr.ac.ir/bitstream/Hannan/ 


\section{OLVASS FELESLEGESET!}

130553/1/Goode\%2C_Ben-Yehuda-Moral_Panics_The_Social_Construction_of_ Deviance\%282009\%29.pdf (Utolsó letöltés: 2020. 03. 18.)

Hier, S. (2003): "Risk and Panic in Late Modernity: Implications of the Converging Sites of Social Anxiety." British Journal of Sociology 54(1): 3-20.

Kitzinger D. (2000): A morális pánik elmélete. Replika 40(6): 23-48.

https://www.replika.hu/system/files/archivum/replika_40-02_kitzinger.pdf, (Utolsó letöltés: 2020. 03.18.)

Lázár D. - Sik E. (2019): A morálipánik-gomb 2.0. Mozgó Világ 11: 15-32. https://www.academia.edu/40971554/A_mor\%C3\%A1lisp\%C3\%A1nik- gomb_ 2.0 (Utolsó letöltés: 2020. 03. 26.)

Messing V. - Ságvári B. (2016): „Ahogy »másokhoz« viszonyulunk, az tükrözi azt, amilyenek magunk vagyunk." A magyarországi idegenellenesség okairól. socio. hu, 6(2): 17-37. https://socio.hu/uploads/files/2016_2/messing_sagvari.pdf (Utolsó letöltés: 2020. 03.18.)

Simonovits B. - Bernát A. (szerk.) (2016): The Social Aspects of the 2015 Migration Crisis in Hungary. TÁRKI, Budapest. http://old.tarki.hu/hu/news/2016/kitekint/20160330_refugees.pdf (Utolsó letöltés: 2020. 03.18.)

Snel, E. (2003): „Morele Paniek Beheerst het Integratiedebat.” Roodkoper: Onafhankelijk Maandblad voor Cultuur, Religie en Politiek 8(1): 12-16.

Thompson, K. (1998): Moral Panics, London, Routledge.

Ungar, S. (2001): "Moral Panic Versus the Risk Society: The Implications of the Changing Sites of Social Anxiety." British Journal of Sociology 52(2): 271-291. http:// www.penelopeironstone.com/UngarMoralPanic.pdf (Utolsó letöltés: 2020. 03. 18.) 